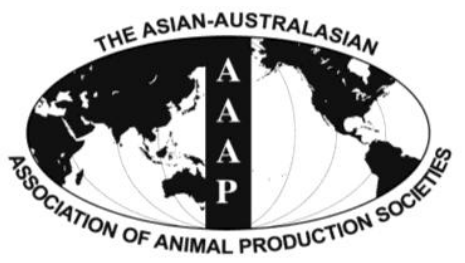

Asian-Aust. J. Anim. Sci.

Vol. 25, No. 11 : 1559-1567 November 2012

http://dx.doi.org/10.5713/ajas.2012.12213

www.ajas.info

pISSN 1011-2367 elSSN 1976-5517

\title{
Effects of Temperature during Moist Heat Treatment on Ruminal Degradability and Intestinal Digestibility of Protein and Amino Acids in Hempseed Cake
}

\author{
L. Karlsson ${ }^{1,2}$,*, M. Ruiz-Moreno ${ }^{1}$, M. D. Stern ${ }^{1}$ and K. Martinsson ${ }^{2}$ \\ ${ }^{1}$ Department of Animal Science, University of Minnesota, St. Paul, MN 55108-6118, USA
}

\begin{abstract}
The objective of this study was to evaluate ruminal degradability and intestinal digestibility of crude protein (CP) and amino acids (AA) in hempseed cake (HC) that were moist heat treated at different temperatures. Samples of cold-pressed HC were autoclaved for $30 \mathrm{~min}$ at 110,120 or $130^{\circ} \mathrm{C}$, and a sample of untreated $\mathrm{HC}$ was used as the control. Ruminal degradability of $\mathrm{CP}$ was estimated, using the in situ Dacron bag technique; intestinal CP digestibility was estimated for the $16 \mathrm{~h}$ in situ residue using a three-step in vitro procedure. AA content was determined for the $\mathrm{HC}$ samples (heat treated and untreated) of the intact feed, the $16 \mathrm{~h}$ in situ residue and the residue after the three-step procedure. There was a linear increase in RUP $(p=0.001)$ and intestinal digestibility of RUP ( $p=$ 0.003 ) with increasing temperature during heat treatment. The $130^{\circ} \mathrm{C}$ treatment increased RUP from 259 to $629 \mathrm{~g} / \mathrm{kg} \mathrm{CP}$, while intestinal digestibility increased from 176 to $730 \mathrm{~g} / \mathrm{kg}$ RUP, compared to the control. Hence, the intestinal available dietary CP increased more than eight times. Increasing temperatures during heat treatment resulted in linear decreases in ruminal degradability of total AA ( $p=$ $0.006)$ and individual AA $(\mathrm{p}<0.05)$ and an increase in intestinal digestibility that could be explained both by a linear and a quadratic model for total AA and most individual AA $(\mathrm{p}<0.05)$. The $130^{\circ} \mathrm{C}$ treatment decreased ruminal degradability of total AA from 837 to 471 $\mathrm{g} / \mathrm{kg}$, while intestinal digestibility increased from 267 to $813 \mathrm{~g} / \mathrm{kg}$ of rumen undegradable AA, compared with the control. There were differences between ruminal AA degradability and between intestinal AA digestibility within all individual $\mathrm{HC}$ treatments ( $<<0.001)$. It is concluded that moist heat treatment at $130^{\circ} \mathrm{C}$ did not overprotect the $\mathrm{CP}$ of $\mathrm{HC}$ and could be used to shift the site of CP and AA digestion from the rumen to the small intestine. This may increase the value of HC as a protein supplement for ruminants. (Key Words: Cannabis sativa, Heat Treatment, Amino Acids, Ruminal Degradability, Intestinal Digestibility)
\end{abstract}

\section{INTRODUCTION}

Proteins fed to ruminants are broken down by microbes in the rumen and used for microbial protein synthesis. Although some feed proteins escape the rumen without being degraded. Amino acids (AA) that are required by the ruminant originate from both microbial protein and rumen undegradable protein (RUP) and, to a lesser extent, from endogenous protein (NRC, 2001). Strategies that are used to increase conversion of feed $\mathrm{N}$ into meat or milk include feeding to achieve greater microbial protein synthesis, to balance the supply of rumen degradable protein (RDP) and RUP, and to improve the supply of essential AA (Schwab et

\footnotetext{
* Corresponding Author: Linda Karlsson. Tel: +47-916-49895, Fax: +47-739-14134, E-mail: linda.karlsson@fkf.no

2 Department of Agricultural Research for Northern Sweden, Swedish University of Agricultural Sciences (SLU), SE-90183 Umeå, Sweden.
}

Submitted Apr. 22, 2012; Accepted Jun. 1, 2012; Revised Aug. 9, 2012 al., 2005). Accurate determination of the amount of RDP and the intestinal digestibility of RUP is required to estimate feed protein available to ruminants by nutritional models. Individual AA have been shown to differ with respect to their rumen degradability (Weisbjerg et al., 1996; Harstad and Prestløkken, 2001), so the RUP AA profile in a feed may differ from the feed AA profile. Hence, it may be incorrect to use the AA composition of the feed when predicting the supply of individual dietary AA to the small intestine.

A range of feed processing methods are applied to protect supplemented feed protein from microbial degradation in the rumen and thereby increase the amount of AA available for digestion in the small intestine. Heat treatment is a common method that can be performed in a number of ways, including moist heat treatment of feed, using an autoclave with a positive relationship between steam pressure and temperature (Van der Poel et al., 2005). Several in situ and in vitro studies demonstrated that it is 
possible to shift protein digestion in different oilseed feedstuffs from the rumen to the small intestine by heat treatment, without decreasing total digestibility (McKinnon et al., 1995; Dakowski et al., 1996; Mustafa et al., 1999a). However, temperatures that are too high may overprotect the protein, resulting in a decrease in post-ruminal availability (McKinnon et al., 1995; Dakowski et al., 1996).

In recent years, there has been increasing interest in using alternative protein crops in livestock production. Hemp (Cannabis sativa L.) is an ancient crop, cultivated for fiber and oil, that has received renewed attention during the last decade. The residue left after mechanical or solvent extraction of the oil from hempseed is a cake or a meal rich in protein and fiber (Callaway, 2004). A few studies have been published investigating the use of hempseed as a protein feed. These studies included hempseed in diets for lambs (Mustafa et al., 1999b ; Karlsson and Martinsson, 2011), growing cattle (Gibb et al., 2005; Hessle et al., 2008; Turner et al., 2008) and dairy cows (Karlsson et al., 2010). Mustafa et al. (1999b) found a low effective protein degradation (EPD) of $394 \mathrm{~g} / \mathrm{kg}$ CP in hempseed meal estimated in situ. An in vitro study by Karlsson et al. (2009) showed that cold pressed hempseed cake (HC) had an EPD value of $330 \mathrm{~g} / \mathrm{kg} \mathrm{CP}$. Contrary to these observations, the estimated EPD value of $\mathrm{HC}$ was $709 \mathrm{~g} / \mathrm{kg} \mathrm{CP}$ in an in situ study (Karlsson and Martinsson, 2011). In addition, a low intestinal RUP digestibility was found, resulting in a much lower value for intestinally available CP of $\mathrm{HC}(90 \mathrm{~g} / \mathrm{kg}$ $\mathrm{CP})$ than the value for hempseed meal $(654 \mathrm{~g} / \mathrm{kg} \mathrm{CP})$ reported by Mustafa et al. (1999b). Heat treatment may be an option to decrease EPD in HC and thereby increase RUP and supply of AA to the post-ruminal tract. A high intestinal digestibility of RUP is required to ensure that there is no decrease in total available $\mathrm{CP}$ from feed. To the authors' knowledge, there are no published studies investigating possibilities for altering site of protein digestion of $\mathrm{HC}$. The objective of this study was to evaluate ruminal degradability and intestinal digestibility of $\mathrm{CP}$ and AA in $\mathrm{HC}$, exposed to moist heat treatment at various temperatures.

\section{MATERIALS AND METHODS}

\section{Feed samples and chemical analysis}

Hempseed (Cannabis sativa L., cv. Finola) was coldpressed to produce HC (Täbypress Type 90, Skepsta Maskiner AB, Örebro, Sweden) by a commercial oil producer. The HC was ground and passed through a $2 \mathrm{~mm}$ screen (Thomas - Willey laboratory mill Model 4, PA, USA) and samples of approximately $100 \mathrm{~g}$ were autoclaved for $30 \mathrm{~min}$ at $110^{\circ} \mathrm{C}(\mathrm{HC} 110), 120^{\circ} \mathrm{C}(\mathrm{HC} 120)$ or $130^{\circ} \mathrm{C}$ (HC130), using a direct steam heated sterilizer
(Consolidated Stills and Sterilizers, Boston, MA, USA). Different temperatures were chosen in order to allow us to evaluate the effects of increasing temperature on rumen degradability and intestinal digestibility of protein and AA in HC. After an exhaust period of $1 \mathrm{~min}$ in the autoclave, samples were allowed to cool for $24 \mathrm{~h}$ before being sealed in plastic bags. A sample of untreated HC was kept as a control ( $\mathrm{HCO})$.

Chemical composition data presented in Table 1 were determined as described by Karlsson and Martinsson (2011). Otherwise, dry matter (DM) content was determined by drying at $100^{\circ} \mathrm{C}$ for $24 \mathrm{~h}$, and $\mathrm{CP}$ content was determined according to AOAC (1984) as Kjeldahl-N $\times 6.25$ using a 2020 Digestor and a 2300 Kjeltec Analyser Unit (Foss Tecator AB, Höganäs, Sweden).

\section{In situ incubations}

Rumen degradability of $\mathrm{HC}$ protein was determined by measurements of in situ CP disappearance (Ørskov and McDonald, 1979). Approximately $0.5 \mathrm{~g}$ of feed was weighed into Dacron bags (Ankom R510, 50×100 mm, 50 $\mu \mathrm{m})$ and incubated in duplicates in the rumen of a cannulated lactating cow (Montbeliarde $\times($ Jersey $\times$ Holstein $)$ ) for 2, 8, 16, 24 or $48 \mathrm{~h}$. The cow was fed approximately $3 \%$ of body weight of a diet based on corn silage (33\%), ground corn $(20 \%)$, alfalfa hay $(16 \%)$, cottonseed $(7.5 \%)$, soybean meal $(7.4 \%)$, soybean hulls $(3.7 \%)$, canola meal (3.7\%), corn distiller grain $(2.8 \%)$ and molasses $(2.6 \%)$ on DM basis. Bags were soaked in $39^{\circ} \mathrm{C}$ tap water for $15 \mathrm{~min}$, prior to incubation in the rumen. After removal from the rumen, bags were rinsed in cold tap water until the runoff was clear, and oven-dried at $55^{\circ} \mathrm{C}$ for $48 \mathrm{~h}$. Zero-time disappearance, assumed to be the soluble fraction, was determined by soaking duplicates of each treatment in $39^{\circ} \mathrm{C}$ tap water for $15 \mathrm{~min}$ (rinsing every third min for $1 \mathrm{~min}$ ). All residues were analyzed for $\mathrm{CP}$ as described above. Proportions of RDP and RUP were calculated according to the equation of Ørskov and McDonald (1979) assuming a passage rate of $0.06 / \mathrm{h}$

Table 1. Chemical composition of hempseed cake

\begin{tabular}{lc}
\hline & Hempseed cake \\
\hline $\mathrm{DM}(\mathrm{g} / \mathrm{kg})$ & 927 \\
Ash $(\mathrm{g} / \mathrm{kg} \mathrm{DM})$ & 69 \\
$\mathrm{CP}(\mathrm{g} / \mathrm{kg} \mathrm{DM})$ & 336 \\
Fat $(\mathrm{g} / \mathrm{kg} \mathrm{DM})$ & 127 \\
Starch $(\mathrm{g} / \mathrm{kg} \mathrm{DM})$ & 7 \\
Neutral detergent fiber $(\mathrm{g} / \mathrm{kg} \mathrm{DM})$ & 382 \\
Acid detergent fiber $(\mathrm{g} / \mathrm{kg} \mathrm{DM})$ & 336 \\
Buffer soluble CP $(\mathrm{g} / \mathrm{kg} \mathrm{CP})$ & 191 \\
Non-protein nitrogen $(\mathrm{g} / \mathrm{kg} \mathrm{CP})$ & 66 \\
Acid detergent insoluble CP $(\mathrm{g} / \mathrm{kg} \mathrm{CP})$ & 79 \\
\hline
\end{tabular}

$\mathrm{DM}=$ Dry matter; $\mathrm{CP}=$ Crude protein . 
To obtain rumen undegradable material, 12 additional bags per treatment, each containing a $1.2 \mathrm{~g}$ sample, were incubated in the rumen for $16 \mathrm{~h}$ (representing the feed that would escape from the rumen at a passage rate of $0.06 / \mathrm{h}$ ). Samples were washed and dried as described above and then pooled before $\mathrm{CP}$ determination and estimation of intestinal digestibility. The in situ procedure described above was repeated in two consecutive runs using the same feeds and the same cow.

\section{In vitro intestinal digestibility}

Intestinal digestion of the RUP fraction was estimated using the three-step in vitro procedure, TSP (Calsamiglia and Stern, 1995), modified by Gargallo et al. (2006). Approximately $1.0 \mathrm{~g}$ of the pooled rumen-exposed residue was weighed into Dacron bags (Ankom R510, 50×100 mm, $50 \mu \mathrm{m}$ ) (four per treatment) and placed in a Daisy ${ }^{\text {II }}$ incubator (ANKOM, Fairport, NY). Samples were incubated in $2 \mathrm{~L}$ of pre-warmed $0.1 \mathrm{~N} \mathrm{HCl}$ solution adjusted to $\mathrm{pH} 1.9$ and containing $1 \mathrm{~g} / \mathrm{L}$ of pepsin (Sigma P-7000, Sigma Chemicals Co., St Louis, MO, USA), they were rotated constantly at $39^{\circ} \mathrm{C}$ for $1 \mathrm{~h}$. Samples were rinsed in cold tap water until the runoff was clear before they were incubated in $2 \mathrm{~L}$ of pre-warmed pancreatin (Sigma P-7545, Sigma Chemicals Co., St Louis, MO, USA) solution (0.5 M $\mathrm{KH}_{2} \mathrm{PO}_{4}$ buffer standardized at $\mathrm{pH} 7.8$ and containing 50 ppm of thymol and $3 \mathrm{~g} / \mathrm{L}$ of pancreatin), rotated constantly at $39^{\circ} \mathrm{C}$ for $24 \mathrm{~h}$. After incubation, samples were rinsed in cold tap water until the runoff was clear and oven-dried at $55^{\circ} \mathrm{C}$ for $48 \mathrm{~h}$. Residues were pooled by sample for CP and AA analyses.

\section{Amino acid analysis}

Samples of HC (HC0, HC110, HC120 and HC130) were analyzed for AA by a commercial laboratory, using a Hitachi High-Technologies Model L-8900 AA analyzer. The instrument incorporated a cation exchange column, multiple sequential lithium-based eluents, and lithium hydroxide for column regeneration. Absorbance was measured at 440 and $570 \mathrm{~nm}$ following post-column color development by Ninhydrin reagent at $131^{\circ} \mathrm{C}$. Degradability and digestibility of all individual AA were calculated on the basis of quantification by acid-stable hydrolysis, performed on the intact $\mathrm{HC}$, after $16 \mathrm{~h}$ in situ incubation and after the TSP from the two repeated runs. The cystine and methionine content in the intact $\mathrm{HC}$ from the second run were also quantified by means of performic acid hydrolyzed AA analysis.

Because the $16 \mathrm{~h}$ residue may not represent the protein that would escape from the rumen at a passage rate of $0.06 / \mathrm{h}$, ruminal AA degradability was calculated using the computed RUP value. Assuming that the AA profile of $16 \mathrm{~h}$
$\mathrm{CP}$ in situ residue will be representative for the RUP, rumen degradability and intestinal digestibility of AA (g/kg AA) were calculated using the equations:

AA degradability $=1,000-(($ AA concentration in $16 \mathrm{~h}$ $\mathrm{CP}$ residue/AA concentration in feed $\mathrm{CP}) \times \mathrm{RUP})$

AA digestibility $=1,000-(\mathrm{AA}$ concentration in TSP CP residue/AA concentration in $16 \mathrm{~h} \mathrm{CP}$ residue $) \times(1,000$ intestinal digestibility of RUP)

\section{Statistical analyses}

Data were examined by analysis of variance, using the MIXED procedure in SAS (Littell et al., 2006). The content, ruminal degradability and intestinal digestibility of $\mathrm{CP}$ and AA were evaluated using the model:

$$
Y_{i j}=\mu+\alpha_{i}+b_{j}+e_{i j}
$$

where: $\mu$ is the overall mean, $\alpha_{i}$ is the main effect of treatment ( $\mathrm{i}=4$; HC0, $\mathrm{HC} 110, \mathrm{HC} 120, \mathrm{HC} 130), b_{j}$ is the random effect of run $(\mathrm{j}=2)$ and $e_{i j}$ is the residual error. Treatment effect was divided into the following orthogonal comparisons: i) effect of heat treatment (control vs other), ii) linear and iii) quadratic effects of temperature during heat treatment. Differences in AA degradability, as well as AA digestibility, within each treatment were evaluated using the model presented above, where: $\mu$ is the overall mean, $\alpha_{i}$ is the main effect of individual and total AA ( $\mathrm{i}=$ $18), b_{j}$ is the random effect of run $(\mathrm{j}=2)$ and $e_{i j}$ is the residual error. Tukey's adjustment was used for multiple comparisons of individual and total AA. In all statistical analyses, differences were considered significant at $\mathrm{p}<0.05$. The effect of treatment on cystine and methionine content in the intact $\mathrm{HC}$ could not be analyzed statistically because there was no replication for the alternative hydrolysis method used for quantification.

\section{RESULTS}

\section{Ruminal degradation and intestinal digestion of crude protein}

In situ ruminal CP disappearance, for the heat treated $\mathrm{HC}$ and untreated control, is shown in Figure 1. Heat treatment decreased CP solubility $(\mathrm{p}<0.001)$ and rate of in situ CP disappearance ( $\mathrm{p}=0.033)$, while it increased RUP $(\mathrm{p}=0.002)$, intestinal digestibility $(\mathrm{p}=0.002)$ and intestinal available dietary $\mathrm{CP}(\mathrm{p}<0.001)$, compared with the control (Table 2). The amount of indigestible CP was not different in the HCO and heat treated HC samples $(p=0.133)$. There was a linear increase in RUP $(p=0.001)$ and intestinal digestibility of RUP ( $p=0.003)$ as temperature increased 


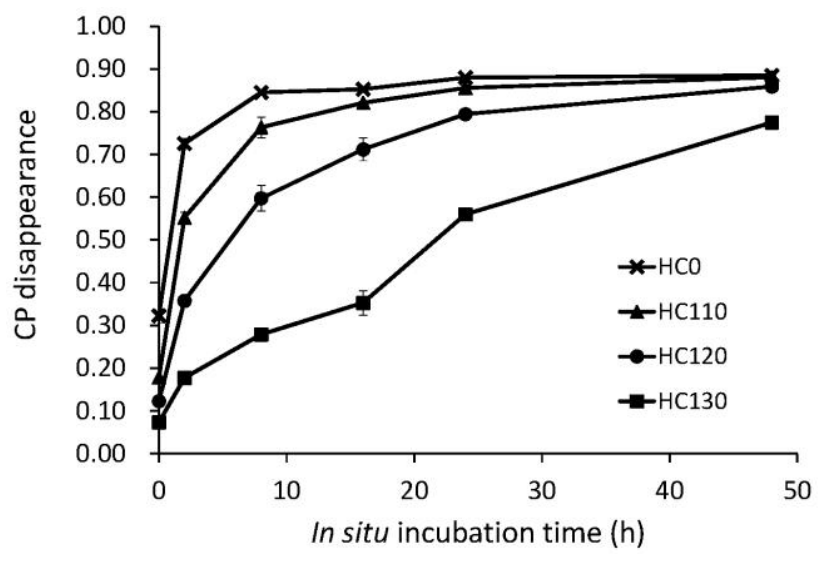

Figure 1. Proportion of in situ crude protein (CP) disappearance in hempseed cake moist heat treated for $30 \mathrm{~min}$ at 110,120 or $130^{\circ} \mathrm{C}$ and in the untreated control ( $\left.\mathrm{HC} 0\right)$.

during heat treatment. Consequently, intestinal available dietary $\mathrm{CP}$ increased by a factor of more than eight as a result of the $130^{\circ} \mathrm{C}$ treatment (Table 2). Changes in site of digestion resulting from moist heat treatment of the $\mathrm{HC}$, are shown in Figure 2 as proportions of feed $\mathrm{CP}$ degraded in the rumen and digested in the small intestine.

\section{Ruminal degradation and intestinal digestion of amino acids}

There were no differences in individual $(\mathrm{p}>0.1)$ or total AA ( $\mathrm{p}=0.741)$ content between $\mathrm{HC} 0$ and heat treaded HC samples (Table 3). The most abundant AA in $\mathrm{HC}$ was glutamic acid, accounting for approximately $181 \mathrm{~g} / \mathrm{kg}$ of total AA. Heat treatment decreased ruminal degradability of total AA and individual AA ( $\mathrm{p}<0.05)$, except methionine, and there were linear decreases $(\mathrm{p}<0.05)$ with increasing temperature during heat treatment (Table 4). Intestinal digestibility of total AA and individual AA, except cystine and methionine, was affected by heat treatment. Higher temperatures resulted in increased intestinal digestibility that could be explained by either a linear or a quadratic model for most of the AA $(\mathrm{p}<0.05)$ (Table 5).

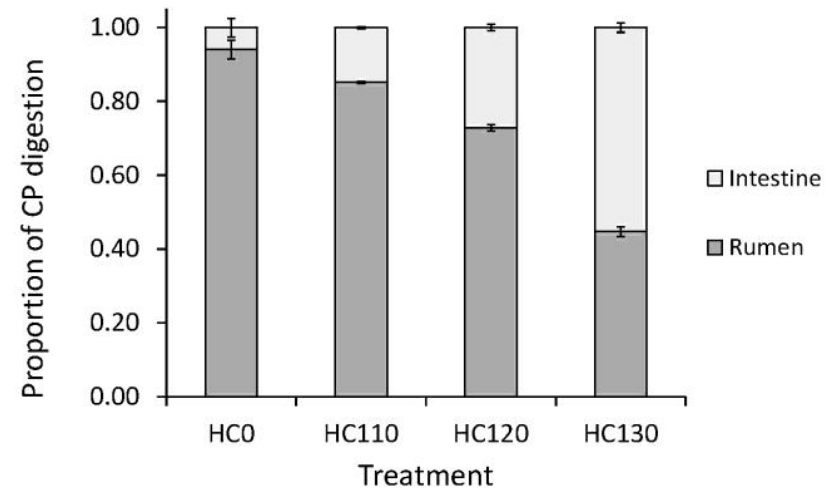

Figure 2. The respective proportion of crude protein (CP) degraded in the rumen and digested in the small intestine estimated for hempseed cake, untreated ( $\mathrm{HC} 0$ ) or moist heat treated at 110,120 or $130^{\circ} \mathrm{C}$.

There were differences between rumen AA degradabilities and between intestinal AA digestibilities within treatments $(\mathrm{p}<0.001)$. Compared to total AA, cystine and methionine had higher ruminal degradability within all treatments. Arginine and phenylalanine had higher and lower degradability, respectively compared with total AA degradability in $\mathrm{HC} 0$ and $\mathrm{HC} 110$. Intestinal digestibility of AA differed from total AA digestibility, particularly in HC130 where arginine, cystine and methionine had higher digestibility $(\mathrm{p}<0.01)$ and phenylalanine and proline had lower digestibility $(\mathrm{p}<0.01)$ compared with that of total AA.

\section{DISCUSSION}

\section{Amino acid content}

The most abundant AA found in HC (glutamic acid, arginine and aspartic acid) were the same as those found in earlier studies of hempseed protein (Callaway, 2004; Wang et al., 2008). The amounts of total AA in the CP of HC were similar to rapeseed meal heated at $150^{\circ} \mathrm{C}$, but lower than untreated rapeseed meal (Dakowski et al., 1996). Total AA content ranged from 784 to $725 \mathrm{~g} / \mathrm{kg}$ CP in rapeseed meal,

Table 2. In situ crude protein (CP) disappearance and in vitro $\mathrm{CP}$ digestion $(\mathrm{g} / \mathrm{kg} \mathrm{CP}$, if not otherwise stated) of hempseed cake, untreated (HC0) or moist heat treated at 110,120 or $130^{\circ} \mathrm{C}$

\begin{tabular}{|c|c|c|c|c|c|c|c|c|}
\hline \multirow{2}{*}{ Item } & \multicolumn{4}{|c|}{ Treatment } & \multirow{2}{*}{ SEM } & \multicolumn{3}{|c|}{ Contrast $(p)$} \\
\hline & $\mathrm{HCO}$ & $\mathrm{HC} 110$ & $\mathrm{HC} 120$ & HC130 & & $\mathrm{T}$ & $\mathrm{L}$ & Q \\
\hline$\overline{\mathrm{CP}}(\mathrm{g} / \mathrm{kg} \mathrm{DM})$ & 345 & 344 & 350 & 355 & 2.0 & 0.137 & 0.036 & 0.935 \\
\hline CP solubility & 323 & 178 & 123 & 73 & 8.5 & $<0.001$ & 0.003 & 0.798 \\
\hline Ruminal CP disappearance (/h) & 0.18 & 0.13 & 0.10 & 0.04 & 0.021 & 0.033 & 0.060 & 0.752 \\
\hline RUP $^{\mathrm{a}}$ & 259 & 339 & 423 & 629 & 15.8 & 0.002 & 0.001 & 0.051 \\
\hline Intestinal digestibility (g/kg RUP) & 176 & 339 & 509 & 730 & 29.4 & 0.002 & 0.003 & 0.528 \\
\hline Intestinally available dietary $\mathrm{CP}^{\mathrm{b}}$ & 47 & 115 & 215 & 459 & 12.0 & $<0.001$ & $<0.001$ & 0.017 \\
\hline Indigestible $\mathrm{CP}^{\mathrm{c}}$ & 212 & 224 & 208 & 169 & 6.8 & 0.133 & 0.004 & 0.182 \\
\hline
\end{tabular}

$\mathrm{T}=\mathrm{HC} 0$ vs heat treated $\mathrm{HC} ; \mathrm{L}=$ Linear effect of temperature during heat treatment; $\mathrm{Q}=$ Quadratic effect of temperature during heat treatment.

${ }^{\mathrm{a}}$ Rumen undegradable protein, calculated at a passage rate of $0.06 / \mathrm{h} .{ }^{\mathrm{b}}$ Calculated as intestinal digestibility $\times \mathrm{RUP}$.

${ }^{c}$ Calculated as RUP-intestinally available dietary CP. 
Table 3. Amino acid composition ( $\mathrm{g} / \mathrm{kg}$ crude protein) of hempseed cake, untreated ( $\mathrm{HC} 0)$ or moist heat treated at 110, 120 or $130^{\circ} \mathrm{C}$

\begin{tabular}{lrrrr}
\hline \multirow{2}{*}{ Amino acids } & \multicolumn{4}{c}{ Treatment } \\
\cline { 2 - 5 } Alanine & HCO & HC110 & HC120 & HC130 \\
Arginine & 88.3 & 31.0 & 30.2 & 31.0 \\
Aspartic acid & 75.5 & 77.9 & 77.7 & 87.5 \\
Cystine & 13.6 & 12.7 & 13.2 & 77.4 \\
Glutamic acid & 130.7 & 133.8 & 130.6 & 13.4 \\
Glycine & 30.0 & 31.1 & 30.3 & 30.8 \\
Histidine & 25.6 & 26.3 & 25.3 & 26.0 \\
Isoleucine & 31.4 & 32.6 & 31.0 & 31.6 \\
Leucine & 51.1 & 52.8 & 51.7 & 52.5 \\
Lysine & 29.1 & 29.2 & 27.7 & 26.8 \\
Methionine & 20.1 & 19.7 & 19.5 & 19.4 \\
Phenylalanine & 36.0 & 37.1 & 36.5 & 36.9 \\
Proline & 30.1 & 31.3 & 30.3 & 30.1 \\
Serine & 32.1 & 32.4 & 33.2 & 34.3 \\
Threonine & 26.0 & 27.2 & 27.0 & 26.7 \\
Tyrosine & 24.2 & 25.2 & 23.8 & 24.1 \\
Valine & 38.4 & 40.1 & 38.3 & 39.2 \\
Total amino acids & 712.1 & 732.1 & 712.2 & 723.3 \\
\hline
\end{tabular}

untreated or heat treated at 130,140 and $150^{\circ} \mathrm{C}$. They found that higher temperatures resulted in lower contents of total AA. This effect on total AA was not found in the current study, however we did not evaluate temperatures higher than $130^{\circ} \mathrm{C}$.

For milk production, methionine and lysine are often considered to be the most limiting AA (NRC, 2001); histidine has been found to be the most limiting AA in grass silage-based diets (Vanhatalo et al., 1999). Therefore, the content of these AA in a protein supplement could be of special interest. Metheonine in $\mathrm{HC}$ was higher, while lysine and histidine in $\mathrm{HC}$ were lower, compared with findings of Wang et al. (2008) for hempseed protein isolate. Wang et al. (2008) found hempseed protein to be a richer source of methionine $(13.9 \mathrm{~g} / \mathrm{kg})$ than soya protein. However, the $\mathrm{HCl}$-hydrolysis method that was used in their study could have resulted in an underestimate of the methionine content of both protein sources. Wang et al. (2008) reperted a lysine content of $41.6 \mathrm{~g} / \mathrm{kg}$ and a histidine content of $28.1 \mathrm{~g} / \mathrm{kg}$ for hempseed protein isolate. One explanation to the lower values found in the present study could be that the $\mathrm{CP}$ fraction contains some NPN, which causes a dilution of the AA content in this fraction compared with isolated protein.

\section{Ruminal degradation}

Effects of heat treatment on rumen $\mathrm{CP}$ degradability that were observed in this study are consistent with findings of several studies where oilseed protein feeds have been evaluated. For instance, Dakowski et al. (1996) observed a decrease in EPD of rapeseed meal measured in situ from $730 \mathrm{~g} / \mathrm{kg}$ in untreated meal to $150 \mathrm{~g} / \mathrm{kg}$ in meal heated to $150^{\circ} \mathrm{C}$. Mustafa et al. (1999a) increased RUP after $12 \mathrm{~h}$ in

Table 4. Ruminal degradability of amino acids (g/kg amino acid) in hempseed cake, untreated (HC0) or moist heat treated at 110,120 or $130^{\circ} \mathrm{C}$

\begin{tabular}{|c|c|c|c|c|c|c|c|c|}
\hline \multirow{2}{*}{ Amino acids } & \multicolumn{4}{|c|}{ Treatment } & \multirow{2}{*}{ SEM } & \multicolumn{3}{|c|}{ Contrast $(p)$} \\
\hline & $\mathrm{HCO}$ & $\mathrm{HC} 110$ & $\mathrm{HC} 120$ & HC130 & & $\mathrm{T}$ & $\mathrm{L}$ & Q \\
\hline Alanine & 785 & 737 & 534 & 410 & 54.4 & 0.016 & 0.010 & 0.476 \\
\hline Arginine & 918 & 880 & 681 & 518 & 48.1 & 0.013 & 0.006 & 0.715 \\
\hline Aspartic acid & 799 & 752 & 557 & 427 & 50.2 & 0.014 & 0.008 & 0.532 \\
\hline Cystine & 975 & 964 & 862 & 727 & 25.9 & 0.021 & 0.006 & 0.625 \\
\hline Glutamic acid & 887 & 843 & 641 & 497 & 45.3 & 0.011 & 0.006 & 0.556 \\
\hline Glycine & 789 & 752 & 567 & 453 & 46.9 & 0.015 & 0.009 & 0.455 \\
\hline Histidine & 848 & 803 & 595 & 452 & 36.7 & 0.008 & 0.004 & 0.466 \\
\hline Isoleucine & 802 & 757 & 542 & 404 & 58.5 & 0.013 & 0.008 & 0.474 \\
\hline Leucine & 789 & 742 & 539 & 406 & 52.3 & 0.014 & 0.008 & 0.504 \\
\hline Lysine & 847 & 812 & 608 & 465 & 56.8 & 0.020 & 0.010 & 0.594 \\
\hline Methionine & 944 & 938 & 838 & 777 & 77.7 & 0.139 & 0.065 & 0.719 \\
\hline Phenylalanine & 739 & 691 & 508 & 389 & 53.4 & 0.016 & 0.011 & 0.526 \\
\hline Proline & 772 & 727 & 559 & 446 & 46.4 & 0.013 & 0.008 & 0.519 \\
\hline Serine & 826 & 779 & 587 & 464 & 51.0 & 0.020 & 0.013 & 0.544 \\
\hline Threonine & 787 & 743 & 557 & 422 & 44.3 & 0.016 & 0.009 & 0.611 \\
\hline Tyrosine & 864 & 830 & 627 & 483 & 63.8 & 0.020 & 0.010 & 0.596 \\
\hline Valine & 776 & 731 & 521 & 394 & 53.5 & 0.013 & 0.008 & 0.419 \\
\hline Total amino acids & 837 & 793 & 605 & 471 & 40.3 & 0.011 & 0.006 & 0.549 \\
\hline
\end{tabular}

$\mathrm{T}=\mathrm{HCO}$ vs heat treated $\mathrm{HC} ; \mathrm{L}=$ Linear effect of temperature during heat treatment; $\mathrm{Q}=$ Quadratic effect of temperature during heat treatment. 
Table 5. In vitro intestinal digestibility of rumen undegraded amino acids ( $\mathrm{g} / \mathrm{kg}$ amino acid) in hempseed cake, untreated or moist heat treated at 110,120 or $130^{\circ} \mathrm{C}$

\begin{tabular}{|c|c|c|c|c|c|c|c|c|}
\hline \multirow{2}{*}{ Amino acids } & \multicolumn{4}{|c|}{ Treatment } & \multirow{2}{*}{ SEM } & \multicolumn{3}{|c|}{ Contrast $(p)$} \\
\hline & $\mathrm{HCO}$ & HC110 & HC120 & $\mathrm{HC} 130$ & & $\mathrm{~T}$ & $\mathrm{~L}$ & Q \\
\hline Alanine & 241 & 368 & 649 & 771 & 23.5 & $<0.001$ & $<0.001$ & 0.037 \\
\hline Arginine & 488 & 661 & 867 & 925 & 12.6 & $<0.001$ & $<0.001$ & 0.017 \\
\hline Aspartic acid & 227 & 360 & 651 & 777 & 21.6 & $<0.001$ & $<0.001$ & 0.036 \\
\hline Cystine & 420 & 642 & 907 & 943 & 80.2 & 0.070 & 0.103 & 0.196 \\
\hline Glutamic acid & 415 & 572 & 814 & 890 & 14.9 & $<0.001$ & $<0.001$ & 0.015 \\
\hline Glycine & 189 & 316 & 618 & 748 & 23.1 & $<0.001$ & $<0.001$ & 0.033 \\
\hline Histidine & 302 & 471 & 735 & 847 & 12.3 & $<0.001$ & $<0.001$ & 0.015 \\
\hline Isoleucine & 270 & 395 & 680 & 792 & 16.2 & $<0.001$ & $<0.001$ & 0.019 \\
\hline Leucine & 261 & 383 & 659 & 780 & 19.8 & $<0.001$ & $<0.001$ & 0.043 \\
\hline Lysine & 336 & 474 & 739 & 843 & 32.1 & $<0.001$ & $<0.001$ & 0.013 \\
\hline Methionine & 449 & 556 & 821 & 919 & 80.2 & 0.080 & 0.050 & 0.371 \\
\hline Phenylalanine & 164 & 278 & 565 & 708 & 20.9 & $<0.001$ & $<0.001$ & 0.058 \\
\hline Proline & 138 & 257 & 564 & 706 & 27.8 & $<0.001$ & $<0.001$ & 0.047 \\
\hline Serine & 302 & 436 & 715 & 822 & 29.2 & $<0.001$ & 0.001 & 0.050 \\
\hline Threonine & 266 & 383 & 656 & 775 & 25.0 & $<0.001$ & $<0.001$ & 0.052 \\
\hline Tyrosine & 355 & 507 & 761 & 861 & 22.7 & $<0.001$ & 0.002 & 0.071 \\
\hline Valine & 214 & 347 & 638 & 755 & 30.7 & 0.001 & 0.002 & 0.068 \\
\hline Total amino acids & 267 & 412 & 700 & 813 & 19.6 & $<0.001$ & $<0.001$ & 0.024 \\
\hline
\end{tabular}

$\mathrm{T}=\mathrm{HC} 0$ vs heat treated $\mathrm{HC} ; \mathrm{L}=$ Linear effect of temperature during heat treatment; $\mathrm{Q}=$ Quadratic effect of temperature during heat treatment.

situ incubation from 120 to $615 \mathrm{~g} / \mathrm{kg} \mathrm{CP}$, and decreased in vitro $\mathrm{EPD}$ from 747 to $445 \mathrm{~g} / \mathrm{kg} \mathrm{CP}$, by autoclaving mustard meal at $127^{\circ} \mathrm{C}$. There are several factors that may influence the effect of heat treatment, these include temperature, time, moisture level and presence of sugars (Wallace and Falconer, 1992; Van der Poel et al., 2005). Autoclaving sunflower seeds for 10, 20 or 30 min increased RUP by 139 , 143 and $164 \%$, respectively, compared with the untreated control (Mustafa et al., 2003). Although there was little further reduction in $\mathrm{CP}$ degradability as heating time increased, the amount of RUP was higher when heated for $30 \mathrm{~min}$. In the present study, we chose to vary temperature but maintain the same heating time, because temperature per se has been shown to have a clearer effect on in situ CP disappearance than the duration of heating (McKinnon et al., 1995).

Decreases in ruminal CP degradability with increased temperatures can be explained by a decrease in the soluble fraction (wash-out fraction) as well as the tendency towards a decreasing estimated rate of degradation that was found in the present study (Table 2). These results are in agreement with findings reported by Mustafa et al. (1999a), who fractionated true protein according to Sniffen et al. (1992) and found that autoclaving mustard meal resulted in significant increases in the intermediate and slowly degradable fractions (B2 and B3), while there was a decrease in the rapidly degradable fraction (B1).

Even though several studies have shown that heat treatment is an effective method to decrease degradation of $\mathrm{CP}$ in the rumen, studies evaluating production responses of feeding protected protein feeds have produced differing results. Santos et al. (1998) reviewed the literature and concluded that increasing the amount of RUP in the diets of dairy cows did not consistently improve milk production. Increases in RUP often result in decreased RDP and changes in absorbed AA profiles. Jones et al. (2001) found that only primiparous cows increased their milk yield when fed heated rather than unheated canola. In a meta-analysis by Huhtanen and Hristov (2009), ruminal CP degradability did not appear to be a significant factor in predicting milk protein yield or efficiency of $\mathrm{N}$ utilization for milk protein synthesis. Hence, in vivo measurements are needed to determine whether heat treatment of $\mathrm{HC}$ is genuinely beneficial to animal performance.

Ruminal degradability of CP and total AA determined in situ have been shown to be similar, but differences have been found between feedstuffs and between individual AA (Weisbjerg et al., 1996; Harstad and Prestløkken, 2001). In the present study, cystine and methionine had a higher ruminal degradability relative to total AA for all $\mathrm{HC}$ treatments. Hence, their degradability would be underestimated using RDP or total AA degradability as a predictor, especially for the highest temperature treatment. However, degradability and digestibility of AA were calculated using values determined by acid-stable hydrolysis. This procedure typically results in yields below 
the correct values for the sulfur-containing AA cystine and methionine. These two AA should be quantified by performic acid hydrolyzed amino acid analysis to achieve more reliable values for ruminal degradation and intestinal digestion.

\section{Intestinal digestion}

The purpose of heat treating protein supplements is to decrease degradability of feed protein in the rumen, and thereby increase the amount of protein that can be digested in the small intestine. High temperatures may cause heat damage to the protein and thus reduce its total tract digestibility, although no negative effects were observed in the current experiment. The amounts of indigestible CP were similar in heat treated $\mathrm{HC}$ and the control. Hence, higher amounts of RUP resulted in an increased intestinal digestibility of this fraction, which has also been found in previous studies (Lund et al., 2008; Solanas et al., 2008). Increased in vitro protein digestibility of beans resulting from heat treatment, has been explained by reduced antinutritional factors such as tannins and trypsin inhibitor activity (Shimelis and Rakshit, 2005). However, reduced digestibility due to anti-nutritional factors seems to be less of a problem in HC. Hemp protein isolates have been shown to have higher in vitro digestibility ( 88 to $91 \%$ ) than soya protein isolate $(71 \%)$ after pepsin and trypsin digestion (Wang et al., 2008). In the present study, the amount of indigestible CP after the TSP was considerably higher than content of acid detergent insoluble CP (Table 1), which often is used as an indicator of unavailable protein in feeds (Goering et al., 1972).

Results of the current experiment do not allow us to define the optimal temperature for maximizing intestinally available dietary $\mathrm{CP}$ and AA. Moist heat treatment at $130^{\circ} \mathrm{C}$ resulted in the largest amount of RUP with the highest intestinal digestibility. This was the highest temperature that could be achieved in the autoclave but it is possible that higher temperatures could be applied without impairing intestinal digestibility of protein. However, heating rapeseed meal to $145^{\circ} \mathrm{C}$ was shown to reduce in situ intestinal CP disappearance relative to an untreated control, while there were no negative effects on post-ruminal $\mathrm{CP}$ availability when meal was heated to $125^{\circ} \mathrm{C}$ (McKinnon et al., 1995). Dakowski et al. (1996) found higher intestinal digestibility of $\mathrm{CP}$, total AA and individual AA in rapeseed meal heated to $130^{\circ} \mathrm{C}$ compared with an untreated control, but temperatures of 140 and $150^{\circ} \mathrm{C}$ impaired intestinal digestion.

The Maillard, or non-enzymatic browning, reaction involves condensation of amino groups with sugar residues, which may create permanently bound and indigestible $\mathrm{N}$ (Van Soest, 1994). The reaction is common during heat treatment of feeds and because specific AA such as lysine may be more readily affected than the protein itself, the protein value may be reduced (Van der Poel et al., 2005). For instance, heat treatment of rapeseed meal resulted in reduced lysine content, as well as available lysine, in the study by Dakowski et al. (1996). In the present study, degradability and digestibility of lysine in the heat treated $\mathrm{HC}$ did not differ from that for the total AA, which is in accordance with results found for expander treated feeds (Lund et al., 2008).

In situ intestinal digestibility of $\mathrm{CP}$ and total AA have been shown to be similar in several concentrates and, even though some differences exist between individual AA, it has been suggested that intestinal CP digestibility can be used to predict AA digestion (Weisbjerg et al., 1996; Harstad and Prestløkken, 2001). In this study, total AA had higher intestinal digestibility than $\mathrm{CP}$, indicating that the utilization of AA from $\mathrm{HC}$ in the small intestine might be underestimated if predicted by CP digestibility. Differences between digestibility of individual AA and total AA within individual $\mathrm{HC}$ treatments appeared to be induced by higher treatment temperatures. As discussed previously, values for cystine and methionine need to be confirmed using alternative hydrolysis methods.

\section{IMPLICATIONS}

The results of this study provide novel information of the ruminal degradability and intestinal digestibility of crude protein and amino acids in hempseed cake moist heat treated at different temperatures. It increases the knowledge about a relatively unknown protein source and how processing can be used to affect its feed value. The highest temperature used in this study, $130^{\circ} \mathrm{C}$, resulted in the largest amount of intestinally available dietary crude protein and amino acids. More studies could confirm the degree of protection as the findings in this study show that moist heat treatment of hempseed cake could be used for extensively shifting site of crude protein and amino acid digestion from the rumen to the small intestine. This may increase the value of hempseed cake as a protein supplement for ruminants, but in vivo verification of the production responses is still required.

\section{ACKNOWLEDGEMENTS}

The authors wish to acknowledge the Swedish Farmers Foundation for Agricultural Research for financial support of the project and the SLU Fund for Internationalization of Postgraduate Studies for travel grants for the research visit to The University of Minnesota. We also thank Glen Broderick for comments on the manuscript. 


\section{REFERENCES}

AOAC. 1984. Official methods of analysis. 14th ed. Association of Official Analytical Chemists, Arlington, VA, USA.

Callaway, J. C. 2004. Hempseed as a nutritional resource: an overview. Euphytica 140:65-72.

Calsamiglia, S. and M. D. Stern. 1995. A three-step in vitro procedure for estimating intestinal digestion of protein in ruminants. J. Anim Sci. 73:1459-1465.

Dakowski, P., M. R. Weisbjerg and T. Hvelplund. 1996. The effect of temperature during processing of rape seed meal on amino acid degradation in the rumen and digestion in the intestine. Anim. Feed Sci. Technol. 58:213-226.

Gargallo, S., S. Calsamiglia and A. Ferret. 2006. Technical note: A modified three-step in vitro procedure to determine intestinal digestion of proteins. J. Anim Sci. 84:2163-2167.

Gibb, D. J., M. A. Shah, P. S. Mir and T. A. McAllister. 2005. Effect of full-fat hemp seed on performance and tissue fatty acids of feedlot cattle. Can. J. Anim. Sci. 85:223-230.

Goering, H. K., C. H. Gordon, R. W. Hemken, D. R. Waldo, P. J. Van Soest and L. W. Smith. 1972. Analytical estimates of nitrogen digestibility in heat damaged forages. J. Dairy Sci. 55:1275-1280.

Harstad, O. M. and E. Prestløkken. 2001. Rumen degradability and intestinal indigestibility of individual amino acids in corn gluten meal, canola meal and fish meal determined in situ. Anim. Feed Sci. Technol. 94:127-135.

Hessle, A., M. Eriksson, E. Nadeau, T. Turner and B. Johansson. 2008. Cold-pressed hempseed cake as a protein feed for growing cattle. Acta Agric. Scand., Sect. A - Anim. Sci. 58:136 -145 .

Huhtanen, P. and A. N. Hristov. 2009. A meta-analysis of the effects of dietary protein concentration and degradability on milk protein yield and milk $\mathrm{N}$ efficiency in dairy cows. J. Dairy Sci. 92:3222-3232.

Jones, R. A., A. F. Mustafa, D. A. Christensen and J. J. McKinnon. 2001. Effects of untreated and heat-treated canola presscake on milk yield and composition of dairy cows. Anim. Feed Sci. Technol. 89:97-111.

Karlsson, L., M. Finell and K. Martinsson. 2010. Effects of increasing amounts of hempseed cake in the diet of dairy cows on the production and composition of milk. Animal 4:18541860.

Karlsson, L., M. Hetta, P. Udén and K. Martinsson. 2009. New methodology for estimating rumen protein degradation using the in vitro gas production technique. Anim. Feed Sci. Technol. 153:193-202.

Karlsson, L. and K. Martinsson. 2011. Growth performance of lambs fed different protein supplements in barley-based diets. Livest. Sci. 138:125-131.

Littell, R. C., G. A. Milliken, W. W. Stroup, R. D. Wolfinger and O. Schabenberger. 2006. SAS system for mixed models, 2nd ed. SAS Institute Inc., Cary, NC, USA.

Lund, P., M. R. Weisbjerg and T. Hvelplund. 2008. Profile of digested feed amino acids from untreated and expander treated feeds estimated using in situ methods in dairy cows. Livest. Sci. 114:62-74

McKinnon, J. J., J. A. Olubobokun, A. Mustafa, R. D. H. Cohen and D. A. Christensen. 1995. Influence of dry heat treatment of canola meal on site and extent of nutrient disappearance in ruminants. Anim. Feed Sci. Technol. 56:243-252.

Mustafa, A. F., Y. P. Chouinard, D. R. Ouellet and H. Soita. 2003. Effects of moist heat treatment on ruminal nutrient degradability of sunflower seed. J. Sci. Food Agric. 83:10591064.

Mustafa, A. F., J. J. McKinnon and D. A. Christensen. 1999a. Effect of moist heat treatment on in-vitro degradability and ruminal escape protein and amino acids of mustard meal. Anim. Feed Sci. Technol. 76:265-274.

Mustafa, A. F., J. J. McKinnon and D. A. Christensen. 1999b. The nutritive value of hemp meal for ruminants. Can. J. Anim. Sci. 79:91-95.

NRC. 2001. Nutrient requirements of dairy cattle. 7th rev. ed. ed. National Academy Press, Washington, DC, USA.

Ørskov, E. R. and I. McDonald. 1979. The estimation of protein degradability in the rumen from incubation measurements weighted according to rate of passage. J. Agric. Sci. Camb. 92:499-503.

Santos, F. A. P., J. E. P. Santos, C. B. Theurer and J. T. Huber. 1998. Effects of rumen-undegradable protein on dairy cow performance: A 12-year literature review. J. Dairy Sci. 81:3182-3213.

Schwab, C. G., P. Huhtanen, C. W. Hunt and T. Hvelplund. 2005. Nitrogen requirements of cattle. In Nitrogen and phosphorous nutrition of cattle: reducing the environmental impact of cattle operations (Ed. E. Pfeffer and A. Hristov) pp. 13-70. CABI Publishing, Wallingford, UK.

Shimelis, E. A. and S. Rakshit. 2005. Effect of microwave heating on solubility and digestibility of proteins and reduction of antinutrients of selected common bean (Phaseolus vulgaris L.) varieties grown in ethiopia. Ital. J. Food Sci. 17:407-418.

Sniffen, C. J., J. D. O'Connor, P. J. Van Soest, D. G. Fox and J. B. Russell. 1992. A net carbohydrate and protein system for evaluating cattle diets: II. Carbohydrate and protein availability. J. Anim. Sci. 70:3562-3577

Solanas, E. M., C. Castrillo, M. Jover and A. De Vega. 2008. Effect of extrusion on in situ ruminal protein degradability and in vitro digestibility of undegraded protein from different feedstuffs. J. Sci. Food Agric. 88:2589-2597.

Turner, T., A. Hessle, K. Lundstrom and J. Pickova. 2008. Influence of hempseed cake and soybean meal on lipid fractions in bovine M. longissimus dorsi. Acta Agric. Scand. Sect. A, Anim. Sci. 58:152-160.

Wallace, R. J. and M. L. Falconer. 1992. In vitro studies of conditions required to protect protein from ruminal degradation by heating in the presence of sugars. Anim. Feed Sci. Technol. 37:129-141.

Van der Poel, A. F. B., E. Prestløkken and J. O. Goelema. 2005. Feed processing: effects on nutrient degradation and digestibility. In Quantitative aspects of ruminant digestion and metabolism. 2nd ed. (Ed. J. Dijkstra, J. M. Forbes and J. France) pp. 627-661. CABI Publishing, Wallingford, UK.

Van Soest, P. J. 1994. Nutritional ecology of the ruminant. 2nd ed. Cornell University Press, Ithaca, NY, USA.

Wang, X.-S., C.-H. Tang, X.-Q. Yang and W.-R. Gao. 2008. Characterization, amino acid composition and in vitro digestibility of hemp (Cannabis sativa L.) proteins. Food Chem. 107:11-18. 
Vanhatalo, A., P. Huhtanen, V. Toivonen and T. Varvikko. 1999.
Response of dairy cows fed grass silage diets to abomasal infusions of histidine alone or in combinations with methionine and lysine. J. Dairy Sci. 82:2674-2685.
Weisbjerg, M. R., T. Hvelplund, S. Hellberg, S. Olsson and S. Sanne. 1996. Effective rumen degradability and intestinal digestibility of individual amino acids in different concentrates determined in situ. Anim. Feed Sci. Technol. 62:179-188. 